\title{
Herbal concoctions used in the management of some women-related health disorders in Ibadan, Southwestern Nigeria
}

\author{
${ }^{*}$ Aworinde, D.O., 1Erinoso, S.M., ${ }^{2}$ lbukunOluwa, M.R. and ${ }^{3 T e n i o l a, ~ S . A . ~}$ \\ 1Department of Biological Sciences, Ondo State University of Science and Technology, Okitipupa, Ondo State, \\ Nigeria \\ 2Department of Biology, Adeyemi College of Education, Ondo, Ondo State \\ ${ }^{3}$ Herbarium Unit, Department of Biological Sciences, Ondo State University of Science and Technology, Okitipupa, \\ Ondo State, Nigeria \\ *Corresponding author: daveaworinde@yahoo.com (+234 7038952961, +234 8055361481)
}

Original submitted in on $12^{\text {th }}$ December 2019. Published online at www.m.elewa.org/journals/ on $31^{\text {st }}$ March 2020 https://doi.org/10.35759/JABs.147.2

\begin{abstract}
Objectives: The health conditions of women are broad, and range from pregnancy, gynaecological conditions to overall health/wellness. Ethnomedicinal investigation on plants used in the management of women-related health disorders was conducted in Bode herbal market, Ibadan, Southwestern Nigeria to further emphasize the role of herbal medicine in reproductive health.

Methodology and Results: Ten herb sellers (all females; age range, 35 - 57; mean, 45.80; SD, 7.41) were interviewed in the local language (Yoruba) and their responses recorded. Recipes used in the management of arthritis, fibroid (uterine and menopausal), and obesity/overweight were documented. Thirty (38) plant species belonging to 24 plant families are profiled. The family Fabaceae had the highest number of species $(n=7)$ while stem bark was the most frequently used $(37 \%)$ plant part. Methods of preparations were mainly decoction and steeping of botanicals in alcohol. Administration includes taking one tot/half-a-glass cup, 2 (morning and night) to 3 times daily.

Conclusion and Application of Findings: This study documents and further emphasizes the role of medicinal plants in female reproductive health. Although some of the plants reported here have been cited for the management of diseases such as skin infections and malaria/yellow fever, published reports on their use for women-related health disorders are limited. This research finds application in reproductive disorders in women and alternative approach to health care systems. These plants are presented for experimentation and scientific validation. Efforts should be made to conserve these plants, especially those that show promising bioactivity.
\end{abstract}

Key words: Women, Arthritis, Fibroid, Obesity, Medicinal plant, Nigeria 


\section{INTRODUCTION}

Women hold strategic positions in the world especially in Sub-Saharan Africa where 230 million women of reproductive age live (Pons-Duran, 2019). Their health is broad and complicated ranging from pregnancy and menopause, gynaecological health to overall wellness. Women are afflicted with ailments such as arthritis, rheumatism, gout, menopausal fibroid and menstrual disorders (Singh et al., 2010) while issues relating to reproductive health remain the leading cause of morbidity and mortality in women of child-bearing age worldwide (WHO, 2007). This may be as result of lack of adequate access to reproductive health facilities or religious belief of individuals concerned. Arthritis is a very common disorder in women. It is an informal way of referring to joint pain or diseases and is very common among women and occurs frequently as they get older. The disease can be mild, moderate or severe and includes swelling, pain, stiffness and decreased range of movement. Types are degenerative, inflammatory, infectious, and metabolic arthritis. Risk factors include overweight, family history, age and previous injury (Arthritis Foundation, 2016). Fibroids, variously referred to as uterine myomas, leiomyomas, or fibromas, are the most frequently seen tumours of the female reproductive system. It is estimated that between $20-50 \%$ of women of reproductive age have fibroids. The risk of getting fibroid is high when women approach menopausal age because of long exposure to oestrogen. The risk is even higher with women who are obese and are of African-American identity (UCLA Health, 2016). Overweight and obesity are abnormal or excessive fat accumulation that may impair health. The World Health Organization (WHO) defines overweight as Body Mass Index (BMI) $\geq 25$, and obesity as BMl $\geq 30$. In $2014,39 \%$ of adults ( $\geq 18$ years, $38 \%$ of men and $40 \%$ of women) are overweight with double prevalence between 1980 and 2014 (WHO, 2016). The common health consequences of overweight and obesity are cardiovascular diseases (stroke), musculoskeletal disorders (osteoarthritis), and cancers. Herbal medicines are important part of culture and tradition of the African people. There are some diseases in the human body that medicinal plants can cure even without the use of synthetic drugs (Lowe et al., 2001). Hence, rural and semi-urban people perceive medicinal plants as parts of the major healthcare systems. Furthermore, the tropical region is rich in plants that are used for the management of mild and chronic diseases. Although many western medical practitioners discourage the use of herbal medicines due to uncertainty of the chemical composition, dosages, and toxicity levels (Balick \& Cox, 1996; George, 2011), yet traditional/indigenous societies in Africa and elsewhere have always used plants to promote healing (Bussman, 2006). The renewed interest in herbal medicines has been fuelled by the ineffectiveness and rising cost of synthetic drugs and resistance of organisms to these drugs (Sharma, 1997) as well as the accessibility, affordability and cultural relevance of herbal medicines which are preferred to the high priced healthcare services rendered by orthodox medicine (Bodeker \& Kronerberg, 2002). A few studies on plants used in the management of female reproductive health problems (arthritis, vaginitis, engorged breast) have been reported by Fasola (2015), arthritis (Gbadamosi \& Oloyede, 2014), sexually transmitted infections (Gbadamosi \& Egunyomi, 2014), women-related diseases (Olanipekun et al., 2016) and breast cancer (Gbadamosi \& Erinoso, 2016). Several ethnobotanical/medicinal studies have overlooked or either omitted the significance of herbal medicine in general well-being and specifically female reproductive health. This study therefore was conducted to investigate some women-related health disorders and the plants used in their management with a view to presenting the plants for experimentation and scientific validation. 


\section{METHODS}

Study location: The study was conducted in Bode herbal market in Ibadan South-East Local Government Area. The market is one of the three notable herb markets, the other two being Oje and Oranyan herb markets. Ibadan (Southwestern Nigeria) lies within latitude $7^{\circ} 19^{\prime} 08^{\prime \prime}$ and $7^{\circ} 29^{\prime} 25^{\prime \prime}$ of the equator and longitude $3^{\circ} 47^{\prime} 50^{\prime \prime}$ and $4^{\circ} 0^{\prime} 22^{\prime \prime}$ at a distance of about $154 \mathrm{~km}$ North-East of Lagos. The temperature range is between $27^{\circ} \mathrm{C}$ and $32^{\circ} \mathrm{C}$ with relative humidity of about $75 \%$ to $90 \%$. Ibadan metropolis consists of five local government areas (Ibadan North, North-East, NorthWest, South-East, and South-West) with a population of 2,550,593 people (NBS, 2006; Famuyide et al., 2011). The principal inhabitants of the city, a major centre of trade in agricultural products, are the Yoruba people.

Ethical consideration: The purpose of the study was explained to the informants in the local language

\section{RESULTS AND DISCUSSION}

This study, part of a national project on ethnobotanical studies, was designed to further emphasize the role of herbal medicine in female reproductive health. The combinations, presented in Table 1, served as groundbreaking recipes in the management of some womenrelated health disorders while Table 2 shows the profile of the individual plants. Figs. 1 and 2 show percentage frequency of plant parts, and number of species according to families respectively. Although ten informants were interviewed, only two showed willingness to give "complete" herbal prescriptions for the ailments under study; the others turned down the researchers' plea for complete registration of recipes on
(Yoruba) and informed consent was obtained from each of the respondents.

Ethnomedicinal investigation: Ethnobotanical field methods advocated by Martin (1995) and Sofowora (2008) were adopted. Ten herb sellers (all females) were interviewed (age range, 35 - 57; mean, 45.80; $\mathrm{SD}, 7.41$ ) in the local language (Yoruba) and the responses of two (who showed willingness to give complete recipes) were recorded. Plants implicated in the management of arthritis, fibroid and obesity/overweight were bought from the two herb sellers and taken to the herbarium where they were identified and deposited for reference purposes.

Data Analysis: Data were analysed using descriptive statistics with Epi6-info version 6.04 (CDC, Atlanta, GA, USA) (Dean et al., 1994).

the grounds that studies of this nature bring little or no return to them. Their grievances are tenable and Cox (2001) and Bridges (2004) have succinctly addressed this issue and their recommendations published. The two informants were later rewarded after the interview process. This was done by giving souvenirs to and buying from them the plants implicated in the study. The researchers were, however, careful not to allow incentives or the compensation to influence participants' willingness and response. One of the two informants also gave a recipe on "blood tonic" which she prepares and gives to patients after treating the fibroid and obesity/overweight conditions. 
Aworinde et al., J. Appl. Biosci. 2020 Herbal concoctions used in the management of some women-related health disorders in Ibadan, Southwestern Nigeria

Table 1: Enumeration of recipes used in the treatment of women-related health disorders in Ibadan, Southwestern Nigeria

\begin{tabular}{|c|c|c|}
\hline Ailment & Herbal combinations & Preparation and Administration (Regimen) \\
\hline 1. Uterine fibroid & Luffa cylindrica (seeds - 20 or 60) & $\begin{array}{l}\text { The seeds are shred like melon, ground and rolled } \\
\text { up into } 6 \text { balls using saliva. A ball per day (at } \\
\text { night) is to be inserted into the woman's private } \\
\text { part. To relieve pain, the patient is advised to take } \\
\text { hot pap/analgesic the following morning. The fluid } \\
\text { in the belly will be discharged through the vagina. }\end{array}$ \\
\hline 3. Uterine fibroid & $\begin{array}{l}\text { Piliostigma reticulatum (stem bark) } \\
\text { Allium cepa (white - 1) } \\
\text { potash (as base material) }\end{array}$ & $\begin{array}{l}\text { Decoction in water. One tot/ half a glass cup is to } \\
\text { be taken morning and night }\end{array}$ \\
\hline 4. Menopausal fibroid & $\begin{array}{l}\text { Khaya ivorensis (stem bark) } \\
\text { Strophanthus hispidus (root), } \\
\text { Allium ascalonicum (bulb), } \\
\text { Xylopia aethiopica (fruit - handful) }\end{array}$ & $\begin{array}{l}\text { Decoction in water. One tot/ half a glass cup is to } \\
\text { be taken twice daily }\end{array}$ \\
\hline 5. Obesity and Overweight & $\begin{array}{l}\text { Citrullus lanatus (fruit - big), } \\
\text { Cassia obtusifolia (fruit), } \\
\text { Gambeya africana (fruit), } \\
\text { Allium ascalonicum, } \\
\text { Parinari excels (seed), } \\
\text { Aristolochia repens (root), } \\
\text { Anthocleista djalonensis (root) } \\
\text { Potash }\end{array}$ & $\begin{array}{l}\text { Steeping in alcohol (Schnapps). Half a glass } \\
\text { cup/day or once in three days }\end{array}$ \\
\hline 6. Arthritis & $\begin{array}{l}\text { Mangifera indica (leaf, stem bark } \\
\text { Psidium guajava (leaf), } \\
\text { Parkia biglobosa (leaf, stem bark), } \\
\text { Cymbopogon citratus (leaf), } \\
\text { Khaya ivorensis (stem bark), } \\
\text { Bombax buonopozense (stem bark), } \\
\text { Vitellaria paradoxa (stem bark), } \\
\text { Pseudosedrela kotschyi (stem bark), } \\
\text { Anthocleista djalonensis (stem bark), } \\
\text { Nauclea latifolia (stem bark), } \\
\text { Euphorbia laterifolia (stem), } \\
\text { Ancistrophyllum secundiflorum (stem } \\
\text { bark), } \\
\text { Adenopus breviflorus (fruit), } \\
\text { Opuntia sp., } \\
\text { Euphorbia unispina (stem), } \\
\text { Tetrapleura tetraptera (pod), } \\
\text { Entada gigas (root) } \\
\text { Tetracera alnifolia (stem bark), } \\
\text { Olax subscorpioidea (root) } \\
\text { Securidaca longepedunculata (root) }\end{array}$ & $\begin{array}{l}\text { Decoction in water. One tot/ half a glass cup is to } \\
\text { be taken thrice daily. } \\
\text { Sulphur and Aframomum melegueta, are ground } \\
\text { and worked into Shea butter, to be used as cream } \\
\text { on the affected joint }\end{array}$ \\
\hline
\end{tabular}


Table 2: Profile of plants used in the management of women-related health disorders in Ibadan, Southwestern Nigeria

\begin{tabular}{|c|c|c|c|c|}
\hline $\mathrm{s} / \mathrm{N}$ & Plant & Local name (Yoruba) & Family & Part used \\
\hline 1. & Adenopus breviflorus Benth. & Itagiri & Cucurbitaceae & Fruit \\
\hline 2. & Aframomum melegueta (Roscoe) K. Schum. & Atare & Zingiberaceae & Fruit \\
\hline 3. & Allium ascalonicum $\mathrm{L}$. & Alubosa-elewe & Amaryllidaceae & Bulb \\
\hline 4. & Allium cepa L. & Alubosa-Hausa & Amaryllidaceae & Bulb \\
\hline 5. & Anthocleista djalonensis A. Chev. & Sapo & Gentaniaceae & Stem bark \\
\hline 6. & Ancistrophyllum secundiflorum (P. Beauv.) G. Mann \& H. Wendl. & Okuku & Arecaceae & Stem bark \\
\hline 7. & Aristolochia repens Mill. & Ako-igun & Aristolochiaceae & Root \\
\hline 8. & Bombax buonopozense P. Beauv. & Iponpola & Malvaceae & Stem bark \\
\hline 9. & Bridelia micrantha (Hochst.) Baill. & Asaragbo & Phyllanthaceae & Leaf \\
\hline 10. & Cassia obtusifolia L. & Epa-ikun & Fabaceae & Fruit \\
\hline 11. & Citrullus lanatus (Thunb.) Matsum. \& Nakai & Baara & Cucurbitaceae & Fruit \\
\hline 12. & Cymbopogon citratus $\quad$ (DC.) Stapf. & Ewe tea & Poaceae & Leaf \\
\hline 13. & Detarium microcarpum Harms. & Arira & Fabaceae & Stem bark \\
\hline 14. & Entada gigas (L.) Fawc. \& Rendl. & Agba & Fabaceae & Root \\
\hline 15. & Euphorbia unispina N.E. Br. & Oro-adete & Euphorbiaceae & Stem \\
\hline 16. & Gambeya africana (A. DC.) Pierre & Isu baka & Sapotaceae & Root \\
\hline 17. & Khaya ivorensis A. Chev. & Oganwo & Meliaceae & Stem bark \\
\hline 18. & Lawsonia inermis L. & Laali & Lythraceae & Root, Leaf \\
\hline 19. & Luffa cylindrica (L.) M. Roem. & Kankan-ayaba & Cucurbitaceae & Seed \\
\hline 20. & Mangifera indica $\mathrm{L}$. & Mangoro & Anacardiaceae & Stem bark \\
\hline 21. & Morinda lucida Benth. & Oruwo & Rubiaceae & Root, Leaf \\
\hline 22. & Nauclea latifolia Sm. & Egbesi & Rubiaceae & Stem bark \\
\hline 23. & Olax subscorpioidea Oliv. & Ifon & Olacaceae & Root \\
\hline 24. & Opuntia sp. Mill. & Oro-agogo & Cactaceae & Stem \\
\hline 25. & Parinari excelsa Sabine & Abeere & Chrysobalanaceae & Seed \\
\hline 26. & Parkia biglobosa (Jacq.) R. Br. ex G. Don & Lasangba & Fabaceae & Leaf, Stem bark \\
\hline 27. & Piliostigma reticulatum (DC.) Hochst. & Abafo & Fabaceae & Stem bark \\
\hline 28. & Pseudosedrela kotschyi & Emi-gbegiri & Sapotaceae & Stem bark \\
\hline 29. & Psidium guajava L. & Guofa & Myrthaceae & Leaf \\
\hline 30 & Pterocarpus osun Craib. & Osun & Fabaceae & Stem bark \\
\hline 31. & Securidaca longepedunculata Fresen. & Ipeta & Polygalaceae & Root \\
\hline 32. & Sorghum bicolor (L.) Moench. & Oka-baba & Poaceae & Stem \\
\hline 33. & Strophanthus hispidus DC. & Sagere & Apocynaceae & Root \\
\hline 34. & Tetracera alnifolia Willd. & Opon & Dilleniaceae & Root \\
\hline 35. & Tetrapleura tetraptera (Schumach \& Thonn.) Taub. & Aidan & Fabaceae & Fruit \\
\hline 36. & Theoboma cacao L. & Koko & Malvaceae & Stem bark \\
\hline 37. & Vitellaria paradoxa C.F. Gaertn. & Emi & Sapotaceae & Stem bark \\
\hline 38. & Xylopia aethiopica (Dunal) A. Rich. & Eru & Annonaceae & Fruit \\
\hline
\end{tabular}


Aworinde et al., J. Appl. Biosci. 2020 Herbal concoctions used in the management of some women-related health disorders in Ibadan, Southwestern Nigeria

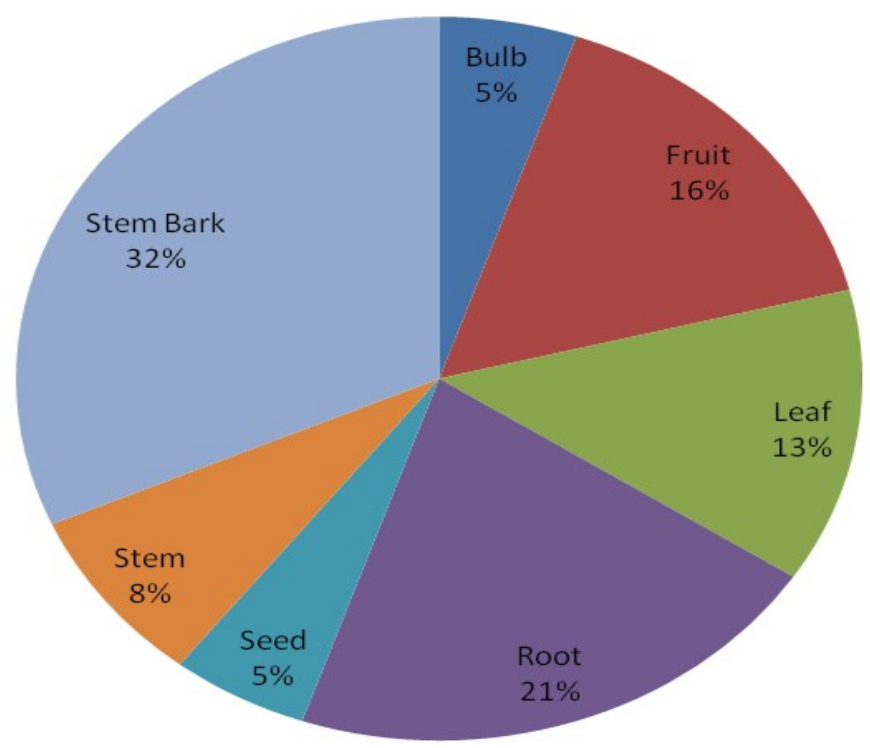

Fig. 1: Percentage frequency of plant parts used in the management of women-related disorder in lbadan, Southwestern Nigeria 


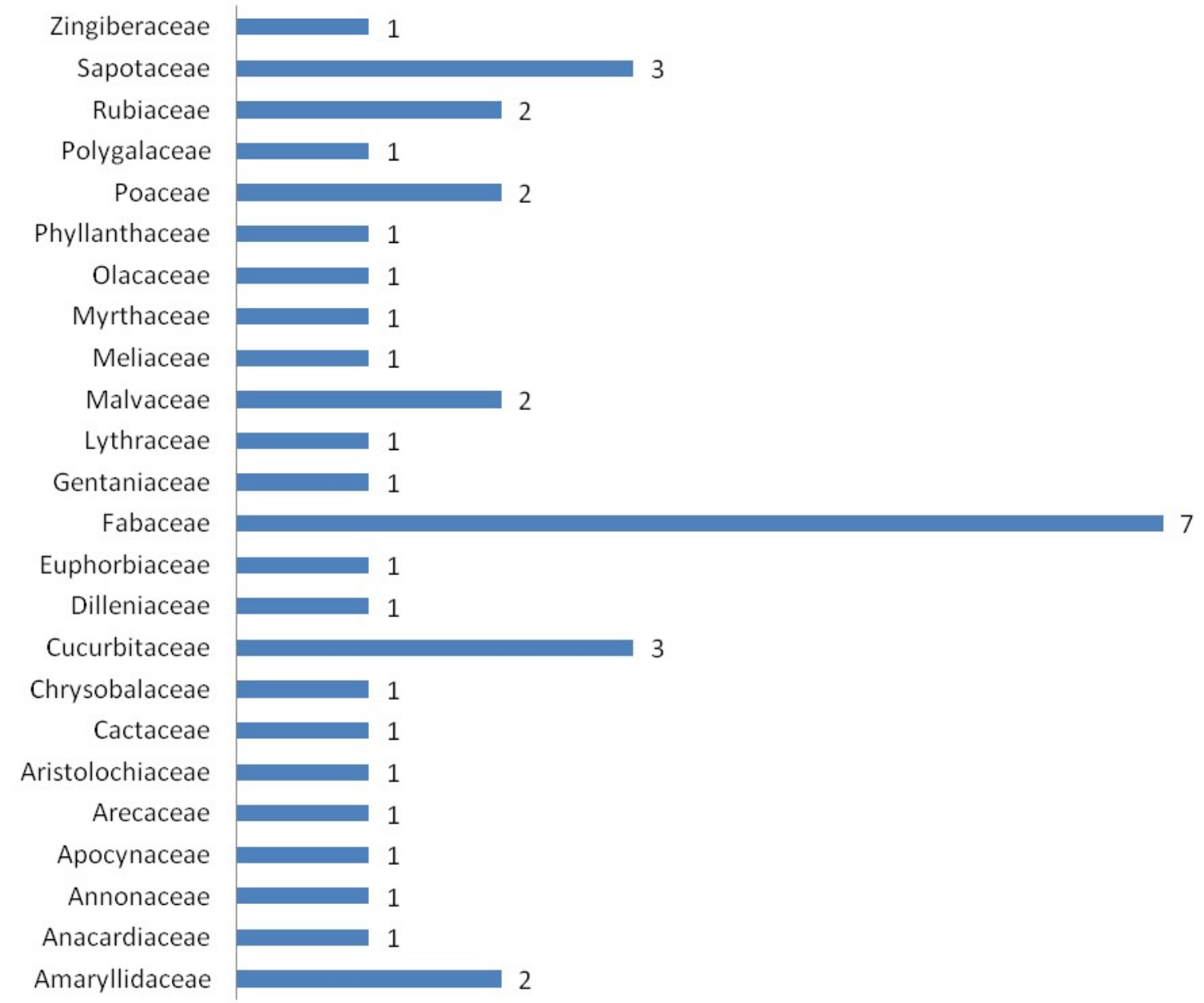

Fig. 2: Species count according to their families

Species count was highest in the family Fabaceae $(n=7)$ while stem bark formed the most frequently used $(32 \%)$ plant part. The results obtained in this study in terms of number of species in plant families and plant parts used are similar to that of Prasad et al. (2014) where the family Fabaceae had the highest species count, and roots and barks are the most frequently used plant parts in the cure of reproductive disorders in Wayanad district, Kerala. Particular emphasis should be given to the conservation of these plant parts. Unsustainable or indiscriminate harvesting of these parts could critically endanger, make vulnerable or worst still drive medicinal plants to extinction. Therefore, efforts should be directed at their sustainability using available conservation strategies and sustainable harvesting techniques. Some plant species in the genera Euphorbia and Lawsonia are reportedly used traditionally for the management of female reproductive health dysfunction in Tana River County, Kenya (Kaingu et al., 2013). Plants that are used worldwide or across regions, for the same purpose, are more likely to be effective. However, some plants have broad-spectrum activities and are used wholly or in combination with other plants. Herb sellers and traditional medical practitioners monopolize traditional botanical knowledge because they do not keep records and botanical knowledge is passed orally from generation to generation. This anomaly could be corrected by encouraging young and educated folks to learn herbal medicine practise and by collaborating with government, universities, NGOs or private agencies in the scientific evaluation of the claimed ethnomedicinal values of some plants. 


\section{CONCLUSION}

This study documents and further emphasizes the role of medicinal plants in female reproductive health. Although some of the plants reported here have been cited for the management of diseases such as skin infections and malaria/yellow fever, published reports on their use for women-related health disorders are

\section{REFERENCES}

Arthritis Foundation, 2016. Arthritis. Available at http://www.arthritis.org/about-arthritis lunderstanding-arthritis/what-is-arthritis.php. Accessed: 31st January, 2017.

Balick M and Cox P, 1996. Plants, Culture and People. Scientific American, New York.

Bodeker $G$ and Kronenberg F, 2002. A public health agenda for complementary, alternative and traditional (indigenous) medicine. American Journal of Public Health. 92: 1582-1591.

Bridges KW, 2004. Editorial - Give and Take. Ethnobotany Research and Applications 2: 75.

Bussmann RW, 2006. Ethnobotany of the Samburu of Mt. Nyiru, South Turkana, Kenya. Journal of Ethnobiology Ethnomedicine. 2: 35-44.

Cox PA, 2001. Ensuring equitable benefits: the Falealupo covenant and the isolation of antiviral drug prostratin from a Samoan Medicinal Plant. Pharmaceutical Biology. 39S: 33-40.

Dean AG, Dean AJ, Coloumbier D, 1994. Epi info: A word processing database and statistics program for epidemiology on microcomputers. Centre for Disease Control and Prevention, Atlanta, GA, USA.

Famuyide OO, Adebayo O, Bolaji-Olutunji KA, Oladeji 0,2011 . Marketing efficiency of Garcinia kola (bitter kola) and Aframomum melegueta (alligator pepper) in Ibadan metropolis, Oyo State. Continental Journal of Agricultural Economics. 5(1): 23-29.

Fasola TR, 2015. An ethnobotanical survey of plants used in the management and treatment of female reproductive health problems in Ibadan, Southwestern Nigeria. Journal of Biology, Agriculture and Healthcare. 5(3): 711.

Gbadamosi IT and Egunyomi A, 2014. Ethnobotanical survey of plants used for the treatment and management of sexually transmitted infections in Ibadan, Nigeria. Ethnobotany Research and Applications. 12: 659-669. limited. This research finds application in reproductive health disorders in women and alternative approach to health care systems. These plants are presented for experimentation and scientific validation. Efforts should be made to conserve these plants, especially those that show promising bioactivity.

Gbadamosi IT and Erinoso SM, 2016. A review of twenty ethnobotanicals used in the management of breast cancer in Abeokuta, Ogun State, Nigeria. African Journal of Pharmacy and Pharmacology. 10(27): 546564.

Gbadamosi IT and Oloyede AA, 2014. The mineral, proximate and phytochemical components of ten Nigerian medicinal plants used in the management of arthritis. African Journal of Pharmacy and Pharmacology. 8(23): 638-643.

George $P, 2011$. Concerns regarding the safety and toxicity of medicinal plants - An overview. Journal of Applied Pharmaceutical Science. 1(6): 40-44.

Kaingu CK, Oduma JA, Mbaria JM, Kiama SG, 2013. Medicinal plants traditionally used for the management of female reproductive health dysfunction in Tana River County, Kenya. TANG Humanitas Medica. 3(2): 1-10.

Lowe $\mathrm{H}$, Payne-Jackson A, Beckstrom-Sternberg SM, Duke JA, 2001. Jamaica's ethnomedicine: its' potential in the healthcare system, Pelican Publishers, Jamaica.

Martin GJ, 1995. Ethnobotany: A people and Plants Conservation Manual. Chapman and Hall, London. 288pp.

NBS, 2006. National Bureau of Statistics, National Population Commission, Abuja, Nigeria.

Olanipekun MK, Arowosegbe S, Kayode JO, Oluwole TR, 2016. Ethnobotanical survey of medicinal plants used in the management of womenrelated diseases in Akoko region of Ondo State, Nigeria. Journal of Medicinal Plants Research. 10(20): 270-277.

Pons-Duran C, Lucas A, Narayan A, Dabalen A, Menedez C, 2019. Inequalities in sub-Saharan African women's and girls' health opportunities and outcomes: evidence from the demographic and health surveys. Journal of Global Health. 9(1): 1-11. 
Prasad AD, Shyma TB, Raghavendra MP, 2014. Traditional herbal remedies used for the management of reproductive disorders in Wayanad district, Kerala. International Journal of Research. 4(2):333-341.

Sharma VP, 1997. Drug resistance: mechanism and management. Singhal RL and Sood OP (Editors). Ranbaxy Science Foundation, New Delhi, India. pp. 67-72.

Singh H, Krishna G, Baske PK, 2010. Plants used in the treatment of joint diseases (rheumatism, arthritis, gout, and lumbago) in Mayurbhanj district of Odisha, India. Reports and Opinion. 2(9): 22-26.

Sofowora A, 2008. Medicinal plants and traditional medicine in Africa (3rd Edition). Spectrum Books Ltd., Ibadan, Nigeria.

UCLA Health, 2016. Fibroids. Available at http://obgyn.ucla.edu/fibroids. Accessed: 31st January, 2017.

World Health Organization (WHO) (2007). Sexually transmitted infections fact sheet. Geneva. http://www.ncbi.nlm.nih.gov/pmc/articles/PMC 2984435/World Health Organization. Accessed: 31st January, 2017.

World Health Organization (WHO, 2016). Obesity and Overweight Fact Sheet. Available at: http://www.who.int/mediacentre/factsheets/fs3 11/en/. Accessed: 31st January, 2017. 